so that it forms a rind round the growth. On examining a scraping microscopically the cells of the growth indicate that it has been a round-celled sarcoma."

Sister's-averuue, Clapham-common, S.W.

\section{A CASE OF HERPES YOSTER WITH LONG.PERSISTING NEURALGIC PAIN AND BELL'S PARALYSIS.}

By G. A. van Someren, M.D Edrn.

A MAN, married, with no family, in good circumstances, of good physique and hitherto in good bealth, came under my care at the latter end of September, 1894, complaining of an eraption on the right side of the face, which extended from the crown of the head on that side to the right shonlder and clavicle, a few spots also existing over the right first rib and over the deltoid of the right arm. The eruption was fully developed and had existed for three or four days before I saw him. He complained of no pain at the time. Neuralgic pains, however, soon occurred, and then in a week or ten days from the first appearance of the eruption he showed a well-marked Bell's paralysis of the affected side. The eruption soon healed soundly, leaving very distinct scarring all over the area affected. The neuralgic pains, however, persisted, and also the Bell's paralysis, though the latter became somewhat better. Bromides, iron, strychnine, sulphate of berberine, and chloride of ammonium were all exhibited, not to mention leeches and liniments. Two and a half months from the date of the primary observation the patient was still liable to recurrent spasmodic attacks of severe and agonising pain over the mastoid process behind the right ear, these pains interfering with sleep. The appetite was good, although very occasionally he refused a meal. The bowels, at first obstinate, acted regularly. The patient walked about and was fairly cheerful. The right side of the face was smooth relatively to the opposite side, but not absolutely so. $\mathrm{He}$ could not close the right eye, or whistle or frown on that side. The tongue was protraded straight. The right cheek hung limply, but he had not much difficulty in moving the food about on that side of the month. The application of the galvanic current, begun in the early stages and long patiently persisted in, had not resulted in any perceptible improvement. What has led to my seeking to put this case on record has been the occurrence of three notices of berpes zoster in THE LANCET ${ }^{1}$ and reperusal of the cases of Dr. Darabseth ${ }^{2}$ and Mr. H. A. Spencer ${ }^{3}$ all of which seem to show an attitude of inquiry which I desire to emphasise by the above record. No doubt in all these cases there exists an inflammation of the nerves affected, but why should this manifest itself so differently in different cases, and why should recovery occur so soon in some cases, as in that of Dr. Darabseth, and be so intractable in mine, which $I$ jadge to be longest in duration of any as regards the persistence of the neuralgic pain? In reference to this point of the severe pain the patient at first located it as over the emergence of the occipital nerve, but later it was fixed at an area exactly represented by thet uncovered by hair behind the ear. The pain came and went. but while it lasted it cansed bim to roll about and grind his teeth with agony. It appeared at no particular period during the twenty-four hours, and analgesics like opium, exalgine, antipyrin, quinine, and the salicylates had no more than a temporary influence. One point more may need mentioning, and that is that the patient seemed to be of a markedly neurotic temperament and had had domestic worry. This seems to have introduced a hysterical element into the case, and I have since tried valerian.

Orange, New South Wales.

\section{The Lancet, Oct. 13th, 1894 \\ The LanceT, May 5th, 1894.}

Foreign University In'telligence.-Erlangen Dr. G. Hanser has been promoted to the chair of General and Anatomical Pathology, vacant by the retirement of Dr. von Zenker.-Gratz: Drs. Drasch and Jarisch have been promoted to Professorships of Histology and Dermatology respectively.-Oporto: Dr. I. do Valle, Professor of General Pathology, has been appointed to succeed Dr. Carlos Lopez in the chair of Materia Medica, Dr. Maximiano de Lemos taking the chair of General Pathology.

\section{A attirtor}

\section{HOS PITAL PRACTICE, BRITISH AND FOREIGN.}

Nulla autem est alia pro certo noscendi via, nisi quamplurimas et mot borum et dissectionum historias, tum aliorum trum proprias collectra habere, et inter se comparare.-Morgagni De Sed. et Caus. Morb., lib. iv. Proœmium.

\section{ST. THOMAS'S HOSPITAL.}

$\triangle$ CASE OF OVARIAN CYST WEIGHING OTER EIGHTY POTNDS SUCCESSFULLY REMOVED FROM A GIRL UNDER

SETENTEEN YEARS OF AGE.

(Under the care of Dr. C. J. CULLINGWORTH.)

THE following account is chiefly of interest from the success which followed the attempt to remove so large a. tumour, and from the other points so clearly indicated in the remarks. It also affords another lesson, if any were needed, as to the uselessness of tapping ovarian cysts, except to relieve urgent symptoms or to diminish shock by the removal of some of the fluid contents before the operation for the removal of very large cysts. Dr. Briddon ${ }^{1}$ has recorded a case in which an attempt at removal of a very large multio locular cyst was unsuccessfully attempted; the cyst weighed $149 \mathrm{lb}$. In the case of a woman aged twenty-siz a tumour which had been growing for three years, and weighed with the fluid contents $91 \mathrm{lb}$,, was removed by Mr. J. E. Abbott; here the case also terminated fatally. It is stated that Dr. Estes ${ }^{3}$ successfully removed a tumour which weighed $125 \mathrm{lb}$. Dr. Kelly ${ }^{4}$ has recorded two successful operations for tumours weighing $100 \mathrm{lb}$. and $116 \mathrm{lb}$. Dr. Goodell ${ }^{5}$ removed one of $112 \mathrm{lb}$., Dr. Ramsay ${ }^{6}$ one of $95 \mathrm{lb}$, and Sir Spencer Wells one of $125 \mathrm{lb}$, and in each instance the patient recovered. These cases prove that it is possible to successfully remove these large tamours of the ovaries, but the risk is, of course, very considerable, and such tumours are rarely seen at the present day, for the diagnosis is now made at an earlier stage than was the rule a year or two ago, and operations performed while the tumour is still small as a rule are very successful. For the notes of this case we are indebted to Dr. W. E. Tinley, senior obstetric house physician.

A girl aged sixteen years was admitted to St. Thomas's Hospital on April 30th, 1895. Until the illness ander discussion commenced she had always been bealthy. She had menstruated once only - viz., in March or April, 1893. In the latter month the patient noticed that she was getting larger, and from that time the enlargement had continued to increase, She was tapped at Christmas, 1893, and a large ouantity of fluid removed. She was tapped again in Febrnary, 1894, and a third time in May, 1894, bat on neither of these occasions with any useful result. She had had no symptoms in connexion with the bladder or rectum; her appetite had been fairly good, and she had only occasionally suffered from sickness. For the previous six montbs she had been almost entirely bedridden, owing to the great size of the tumour. In November, 1893, she was seen in consultation by the consulting surgeon to a provincials hospital, who strongly advised that no operation should be performed. This advice the friends had hitherto acted upon. On her admission into the hospital it was noted that the patient was much emaciated and anxions-looking; her eyes were sunken, and on her cheeks was a patchy redness which easily became livid. She was very weak and could only take a few steps with assistance; she was just able to turn over in bed unassisted. The chest was very thin, the lower ribs were much everted; the thoracic viscera were displaced upwards, so that the beart dulness began at the lower border of the third cartilage, and the apex beat was best felt in the third space. Below this there was a band of (stomach) resonance before the dulness of the tumour began. The liver dulness began at the lower border of the fourth rib cartilage, in the

1 New York Medical Journal, Feh. 8th, 1890.

2 American Journal of Obstetrics. New York, rol. $i ., 1890$.

3 American Practitioner and News, Jan. 3rd, 1891, referred to by Cartledge.

4 Maryland Medical Journal, Baltimore, 1886.

6 Sajous' Annual of the Universal Medical Seiences, vol, ii., 1892, 